\title{
Preventing Urban Crime for Gender Mobility through Human Scale in Trans Semarang Bus Stop
}

\author{
J F Karistie ${ }^{1}$, A R Rakhmatulloh ${ }^{1}$
}

Received: 28 January 2020

Accepted: 23 May 2020

\begin{abstract}
Community safety and crime prevention in the context of the livable city have a tight connection with the practice of human scale. Trans Semarang Bus Rapid Transit as a safe transportation mode is becoming the heart of urban activities that connects various social activities. The ideal condition could be achieved when there is an application of the human scale at the bus stop, without external interference in the process of mobility. As grounded evidence, there are 4 crimes cases that reported on Trans Semarang, not including unreported cases. Indicators in this research cover: the time using BRT, the waiting time at the bus stop, and the changing of human behaviour. Hence, a great human scale characteristic will determine the capability of urban transportation society services. Otherwise, bad human scale characteristics might increase the crime rate. The research will focus on identification of the impact on the human scale variables to the crime rate in Trans Semarang bus stop. It will take place in Semarang Central Business District: Pandanaran, Pemuda and Gajahmada as the center of urban activities served by Trans Semarang. It will conduct a quantitative descriptive research method with the cross-tabulation test. The result is human scale indeed has a positive connection with the crime rate.
\end{abstract}

Keywords: Urban Crome, Human Scale, Gender Mobility, Trans Semarang Bus Stop

\section{INTRODUCTION}

Criminal reports in Trans Semarang Bus Rapid Transit has occurred in the past five years. With the increased of total passengers 10,210,296 million in 2018 there were still some crimes occurred, especially at Trans Semarang bus stop. There was sexual harassment occurred in Corridor II Sisemut-Terboyo in 2015 (Ari, 2015). Another case was a pickpocket happened from April 2016 until 2017 at the route Simpang Lima-Balaikota-R.S. Elizabeth (Permadi G, 2017). The same case currently happened at the bus stop Pemuda with the perpetrators in recidivist status (Parwito, 2018). Trans Semarang informed that within the last 2 years, there were 4 crime cases: pickpocket at Poncol bus stop and sexual harassment at the Polines, Elizabeth and Cakrawala bus stop. One of the cases remained unsolved and could not put on trial.

Those various crimes above is a form of disintegration in city mobility. There is no balance in supply and demand, between public transportation facility and passenger (Martini and Subidia, 2013 in Azali, 2018). The function of public transportation should become a connection between locations (origin-destination point of an individual), and create safety environment for each individual and built environment as well. In creating liveable city is strongly believed as an impact of the number of decreasing crime rate efforts and providing secure to avoid the negative perception and behaviour of public transportation users (Newton, 2004, in Spicer \& Song, 2017). In the smaller scope, the positive behaviour might influence spatial interaction of a route or public transportation bus stop (Spicer, 2012).

\footnotetext{
${ }^{1}$ Urban and Regional Planning Department of Diponegoro University
} 
The urban crimes might occur due to the loss of human scale that influences the routine activities in a certain time (Brunet, 2002 in Tulumello, 2017). According to Newman (1972), human scale is a model that forming individual expression physically. In that context, various variable like easy access to the bus stop, bus stop distance, and spatial interaction become one of the most important factors to form human mobility. The human scale possession will be finite at a lane or certain destination point if the area creates the big proportion of the population (Brantingham and Wong, 1991 in Loukaitou-sideris, Anastasia, Liggett $R$, 2002). This condition might become the beginning of criminal case that often occurs in public transportation (Kelling and Whitzman, 1995 in (Loukaitou-sideris, Anastasia, Liggett R, 2002).

Public transportation crimes theory already discussed in the concept of environmental criminology. This theory focused on the crime analysis in the specific location (static crime, for instance at the bus stop), that influences to the dynamic movement (route or corridor) (Newton, 2004). The weakness of this theory shows majority victims are not willing to share their crime experience to other people. There is a sense of fear (especially for women victims) to share their experience to other people which creating self defense mechanism in them (Ceccato V, 2013; Stark J, 2018).

Information and data about crime victims in Trans Semarang Bus Stop are uncomplete. The information included, either they experienced by themselves, just saw the crime, or even they overheard from several resources. The transportation system should be able to design public space that ensuring people to move flexible in their trips (Stark J, 2018). Research also found that men had the same probability as women as crime victims (Morgan $\mathrm{R}, 2016$ ). Difference experiences which happen to men and women will influence the mobility pattern physically (transportation mode, route and time as well). These problems lead to the gender issues, which the policy should be divided for each group considering the need for space in each scale (Loukaitou-sideris, 2016).

The fear of crimes and effort to obtain the human scale is beyond the gender basis, but still in the form of individual characteristics (Ceccato V, 2017). Gender, in this article, will talk about the respondent role in the mobility which influencing the behavioural pattern. This article will elaborate on the difference between the equality of human scale application towards the crimes in the context of gender exclusivity, and also it sets as a basis to explore the significance of gender mainstreaming.

Finally, the relation between the crime rate and human scale has a connection with urban and transportation planning in Trans Semarang. The study about BRT crime levels is widely observed, but the research by using human scale approach is still low. This research deals with the point of view by observing Trans Semarang bus stops which have already applied human scale principle in Pandama area (Pandanaran-Pemuda-Gajahmada). By pointing out the percentage analysis towards the connectivity and logical thought, it might evaluate the city transportation planning system to improve the service related to human scale. Then, the human scale in Trans Semarang might be applied to gender by optimization in passenger safetiness.

Transportation planning research has been developed for a long time especially related with the existence of geographical and social structure. Researchers underlined that element in human scale has various relations with crimes at the built environment. The challenge does not come to an end to this theory, researchers are trying to study the connectivity between crimes and how ideal mobility in the gender context. The theory which is related to human scale is quite complex, especially to define the specification of the space. Whereas in the context of a city, the human scale might be distinguished in various typology, factor, situation, whether in busy daylight or on a quiet night. Therefore, the focus of this research is to elaborate on the personal needs of BRT passengers whether they experienced the crimes or not based on each of the gender characteristic. 


\section{Human Scale}

The concept of space (a place for people to behave and communicate naturally) and scale (the area from the smallest unit to the largest) is very common in city planning to understand the geographical object in a spatial context (LeFebvre, 1991 in Speer, 2015). LeFebvre also confirmed that the space in certain scale is always changing, in line with the people who use it. Besides that, Yi-Fu-Tuan (1977 in Calcatinge A, 2012) gave an argument that space does not have limitation in a certain scale, as long as the people who do activities in it have a sense of belonging towards its place.

The concept of human scale has been applied since the critics of urban modernism theory came up, which was ruined the basic city planning structure by Le Corbusier (1960), Jane Jacobs (1961), Lewis Mumford (1961), and E.F. Schumacher (1973). Jan Gehl and Lawson (2010) later tried to present a city scale design for the pedestrian who often have obstacles to do their activities. Human scale in city planning is the development of the human scale in Architecture study. Architecture gives more emphasis on the scale which is related to the single building space. But the human scale in city planning is connected with the context of an object and its environment (pedestrian way, open space, mixed land use), through policy planning and inclusive design.

The phenomena about the human scale is hard to see, because the human system directly forms constant measurement towards its surrounding object (as the habit of using the object). Lawson (2001) also emphasized that the human scale was not measured based on an architect's or a planner's will in making the object scale, but how people are able to accept and communicate with the object as a visual form in different perspective. The study about human scale also evaluated the human distance with public transportation access, that the walking ability to reach nearest facility at least in radius 300-400 meters in a day and 800 meters at night (Daniels R, 2011). Lacono, et al (2010) suggested the ideal of human scale is depended on the mobility goal, social-demography characteristics, as well as public transportation quality. Cervero, et al (2009) aimed their research at the achievement of human scale on gender aspect with the measurement of pedestrian space, lights, security, density and the structure of mixed use.

To create an environment which is easy to reach by people, needs a good quality of public transportation mode, including BRT bus stop (Spicer, 2012). People tend not to have a personal connection with the location and BRT space in daily activities. The application of human scale, especially in the CBD area (Central Bussiness District) has connectivity with the special character or often call territorial behaviour (Lawson B, 2001). The relation between territorial behaviour and human perception towards the object is the final goal of the application of human scale.

\section{Environmental Criminology}

The concept of crimes (as a result) at BRT has become the main issue in 1960-1970. The concept was influenced by the environment criminology theory. Jacobs (1961) argued that crimes have close relation with the individual ability to observe his/her environment. Newman (1972) presented the theory of defensible space, that is the individual inability to control his environment because of the crime. The concept of crime intervention then came up in 2003 through the concept of CPTED (Crime Prevention Through Environmental Design) (Shach-Pinsly, 2018). Newton (2015), had a view that human mobility and crimes could be measured on spatial in a certain time. The concept of crime brings the perception that each individual can behave rationally, especially if he/she experienced the crime.

In fact, the crimes case could influence the surrounding or on the contrary, the crimes in the environment influence the crime case at the bus stop. The theory of Cohen and Felson (1979), supported with the research of Spicer and Song (2017), gave an argument that the crimes happened to an individual (like pickpocket or stealing) was hard to avoid. This is 
driven by the routine activities of the victims which motivating the perpetrator to do the crimes and the victims do not have self-protection. In the end, it creates the changing behaviour whether avoiding, temporary changing or total redirect mobility.

In this research, the author defines crime as a behaviour concept that against the law, that will review through the questionnaire distributed to the respondents who experience, see, or listen to the crimes at Trans Semarang bus stop. Experiencing the crimes in the context of being stolen/pickpocket, sexual harassment, physical violence, verbal abuse, fraud, kidnapped. To see the criminal act directly or happened to someone else, watch it from television or social media, read in papers/electronics. To listen about the crimes from friends/family members/neighbours/officers, to get advocation from Trans Semarang, or listen from the radio. Those three parties are considered as the crime experiences although it is in the small form that can be sensed through sight, hearing and touching. The individual might change the behaviour (to protect themselves in public space) or not, because of the minimum transportation choice in urban activity (Robinson, 2011; Vivalta, 2011).

\section{Gender in Mobility}

The safetiness from crimes has become a critical issue in the Gender Study, especially which bringing impact to the women in doing transit (Loukaitou-sideris, 2016; UN Women 2017). The low number of crime cases that are reported to the police department causes inaccuracy in social norm application towards the behaviour of men and women in the public space (Ceccato V, Wiebe D J, Eshraghi B, 2017; Harris C L, Jackson A P, 2017). Including the incorrect way in providing a public facility that causes the victims to experience the crimes. Some reasons are because of the low support to the victims from the environment and the crime site. The victims prefer to keep silent, do not tell others or change transportation mode usage.

Men and women have different reactions (as a victim) when they face the crimes in public transportation. Men usually have more options in mobility, they tend to change the transportation mode or trip route. But women have more limitation in space and time mobility, their relation to public space is weak, although the connectivity between the activities and private space is high (like working mothers or girl students). They tend to use the same transportation mode and only make a little change (more cautious, wear longer clothes, ask travel companion). It means that to find the solution in human scale application for each gender subject, we need to consider about the difference of vulnerability level and its characteristics (Ceccato V, 2017).

Laws policy in gender mainstreaming are not optimal to protect the needs of men and women in doing mobility safely (Ceccato V, 2013; Gekoski et al, 2016; Loukaitou-sideris, 2016). Peter (2013) argued that public transportation company is trying to provide safety service to all people. But as long as it does not fulfill the specification of men and women's needs, it becomes impossible to achieve. The implication is men and women have different preferences in the mobility by considering the location of the trip goal (McDowell L, 1993).

In the context of gender; the accessibility is often connected with the condition of individual's economic. It enforces certain group (usually women and children) to ignore safetiness mobility in public transportation (Ray et al, 2012 in Papagiannakis A, Baraklianos I, 2016). The proximity distance to the bus stop location is often ignored as long as they can do their daily activities. In this case, people do not seem to aware the need of human scale to prevent crimes. Plyusthteva A, (2018) even gave an opinion that it is considered common, and it is a part of gender complexity issue which keeps changing and deals with domestic life. Therefore, the human scale might become the identity to form the close relations between gender subject and his/her environment. Especially in the case of public transportation crimes in Trans Semarang bus stop. 


\section{Case Study: Semarang Central Business District}

Pandama area (Pandanaran-Pemuda-Gajah Mada) has become the central activities and business in Kota Semarang for a long time. Pandama area is one of the main routes of Trans Semarang bus stop and corridor. The total area of Pandama area is about 214 hectare, with the mixed land use for housing, commercial, education, open space, and recreation. Five corridors of Trans Semarang that pass Pandama area are: Corridor I MangkangPenggaron, Corridor II Terboyo-Sisemut, Corridor III Pelabuhan Tanjung Emas-RS. Elizabeth, Corridor IV Cangkiran-Stasiun Tawang and Corridor V Meteseh-PRPP.

The range of the research location is adapted from the distance to the Trans Semarang bus stop which can be reached on foot (400 meters from the origin point, based on SNI 031733-2004 Tata Perencanaan Lingkungan). The pedestrian way in Pandama area simplifies the connection of each location in the area towards the point of BRT Trans Semarang bus stop. Besides that, Caminha et al. (2017) stated that crime phenomena are more vulnerable happened in the city center than in the sub-urban, which could be the same cases in Pandama area as the city center of Semarang.

Pandama area has different land zoning characteristic in each route. Pemuda (3 Trans Semarang bus stops) has characteristic as: government and business center, office, education, and recreation. Gajahmada (4 Trans Semarang bus stops) has the uniqueness of city kampong, and also commercial and service area. Pandanaran (5 Trans Semarang bus stops) has area identity as tourist destination, recreation, and souvenirs center (pusat oleh-oleh). The main bus stop in Pandama area is located at the Balaikota (Pemuda) Transit Bus Stop which serves 5 corridors of Trans Semarang.

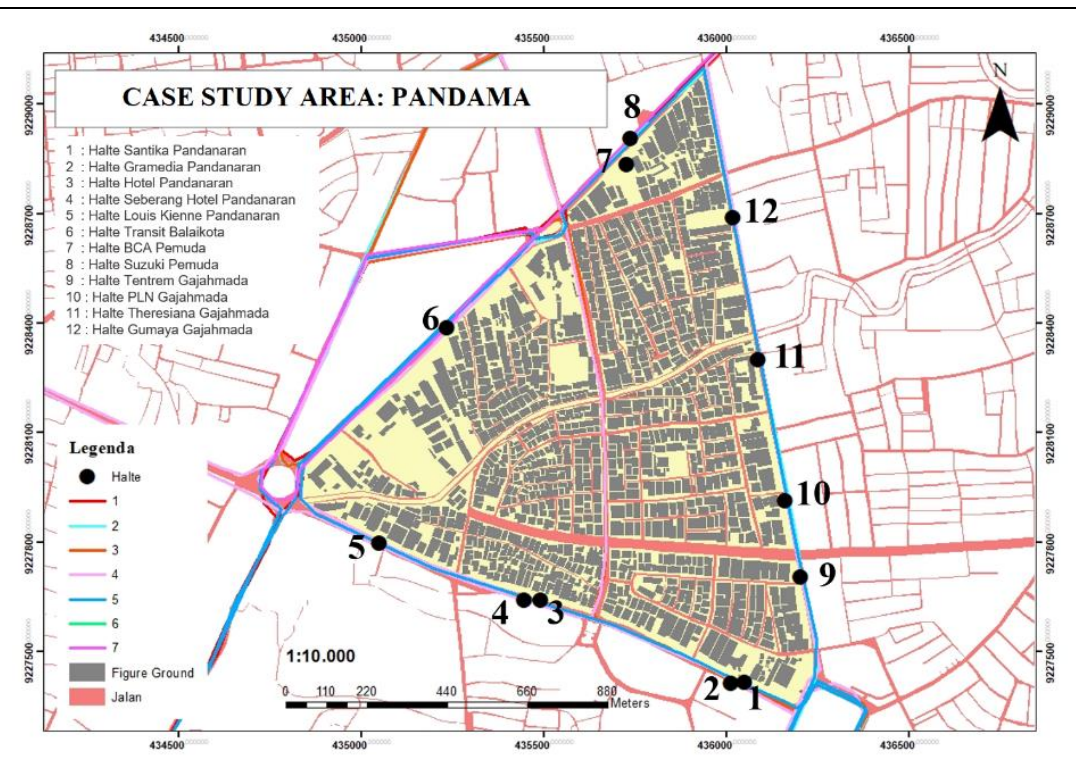

Figure 1. Case Study Area Map: Semarang Central Business District

\section{METHOD}

The data sampling of this research is collected through the questionnaire survey to 100 Trans Semarang passengers at Pandama area. The questions are related with the using of transportation mode towards Trans Semarang bus stop, respondent main activities, departure time to Trans Semarang bus stop, the waiting time for Trans Semarang arrival, the tendency of changing human behaviour, and experiencing crime case. The respondent's criteria is an active Trans Semarang passengers (men or women) above 16 years old, who 
frequently using Trans Semarang for mobility. The number of respondents are taken with the same amount at every route in Pandama area ( \pm 30 respondents for each route) to see the similarity of answer from every respondent. The analysis is presented by descriptive analysis with cross-tabulation analysis. The correlation between variables is based on the percentage of its characteristics.

\section{ANALYSIS AND RESULTS}

\section{Descriptive Analysis}

Women have a complex type of mobility other than men (Verma, Manoj, Rodeja, \& Verma, 2017). The main variable to determine safety mobility in public transportation is how people could reach the bus stop in certain distance and the departure time to start their activities. The following table shows that the respondent tendency to use private vehicle is still low compared with the majority of people who choose to walk to reach the BRT bus stop. Pandama area tend to be more crowded in the morning and in the afternoon, when people go to work or to school and when they come home.

Table 1. The Difference Mobility Type And Activities At BRT Bus Stop In Pandama Area in The Context of Gender (Men And Women)

\begin{tabular}{|c|c|c|c|}
\hline Transportation Mode & Men & Women & Total \\
\hline Walking & $21 \%$ & $41 \%$ & $62 \%$ \\
\hline Bicycle & $1 \%$ & - & $1 \%$ \\
\hline Private Transportation & $5 \%$ & $8 \%$ & $13 \%$ \\
\hline Online Transportation & $5 \%$ & $11 \%$ & $16 \%$ \\
\hline Others a & $3 \%$ & $5 \%$ & $8 \%$ \\
\hline \multicolumn{4}{|l|}{ BRT Using Time } \\
\hline Morning (6.00 a.m.-9.00 a.m.) & $10 \%$ & $21 \%$ & $31 \%$ \\
\hline Daylight (9.00 a.m.-3.00 p.m.) & $6 \%$ & $22 \%$ & $28 \%$ \\
\hline Afternoon (3.00p.m.-6.30p.m.) & $2 \%$ & $10 \%$ & $12 \%$ \\
\hline Morning and Afternoon (6.00-9.00 a.m. and 3.00 p.m.-6.30 p.m.) & $16 \%$ & $13 \%$ & $29 \%$ \\
\hline \multicolumn{4}{|l|}{ Activities } \\
\hline Work & $7 \%$ & $11 \%$ & $18 \%$ \\
\hline School & $22 \%$ & $36 \%$ & $58 \%$ \\
\hline Shopping & - & $6 \%$ & $6 \%$ \\
\hline Recreation & $7 \%$ & $11 \%$ & $18 \%$ \\
\hline \multicolumn{4}{|l|}{ Crime Experience } \\
\hline Experienced the Crime $b$ & $1 \%$ & $5 \%$ & $6 \%$ \\
\hline See the Crime c & $5 \%$ & $4 \%$ & $9 \%$ \\
\hline $\begin{array}{l}\text { Listen about the Crime d } \\
\text { a City Bus, Angkot (Angkutan Umum) } \\
\text { b Robbery, Physical Violence, Sexual Harassment } \\
\text { c Robbery, Sexual Harassment }\end{array}$ & $12 \%$ & $11 \%$ & $23 \%$ \\
\hline d Robbery, Sexual Harassment, Verbal Abuse, Physical Violence & & & \\
\hline
\end{tabular}

Source: Researcher Analysis, 2019

Based on the above table, the crime location did not only happen at the Pandama area bus stops but also in Kaligawe, Milo, Karang Ayu, St. Tawang, Udinus, Gayamsari, Poncol, Imam Bonjol, Unyil, Banyumanik, Mangkang, and Simpang Lima. On the contrary, in Pandama area the crimes especially happened at Balaikota/Pemuda bus stop and Theresiana/Gajahmada bus stop. The crimes at Trans Semarang bus stop is equally spread and not only concentrated in a certain area or land use. The impact of the crime, whether it was experienced, seen, heard by the respondents is various. They lost their wallet or cell 
phone, rude passengers or officers, sexual harassment directly or from distance, and arguing between officer and passenger or passenger with passenger.

The departure time of the respondents in doing their activities with BRT usually is on weekdays. However, it does not mean that the load factor of the BRT trip is low on the weekends. Because most of the respondents use it for the purpose of recreation activities. Most of the respondent activities are at school. Since the Pandama area is one of the education centers, either for high schools (junior/senior) or universities (Udinus, Unisbank), the mobility is high everyday. The existence of Pasar Randusari and Pasar Prembaen as traditional markets in Pandama area, complete the trip destination of the respondents for shopping. And the existence of modern markets like Mall (Paragon, Duta Pertiwi, MG Setos) and shop (Toko Bali on Gajahmada) make the destination trip of BRT is variative.

As explained before, most of the respondents choose not to report the crime case. As a matter of fact, most of the respondents do school activities, work and recreation. It can be assumed that the perpetrators are eyeing the school-age victims (15-23 years). The perpetrators see the vulnerable probability and fear of students if they experience the crime at their age. Both women and men do not have courage to ask help or report the crime, being careless to keep their own property, and less of alertness towards the surrounding because of the minimum experience in the public space. The negative side also there is no research related to the impact of the crime either seen or heard by the respondents at Trans Semarang bus stop. Whereas if the respondents just see or hear about the crimes indirectly, it might influence the trip behaviour pattern (afraid or worry to experience the same crime case).

\section{Cross-Tabulation Analysis}

To know whether there is a connection between time in using BRT and crime experiencing, the chi-square test and connectivity relation is done. The crime experiencing and gender division (men and women) are dependent variable and using time BRT is an independent variable. The variables could estimate that the crimes mostly happen to the respondents who do the activities in the morning (including in the morning and in the afternoon), when they go to and from school or work (the total percentage $17 \%$ men and $15 \%$ women). In other word, crimes mostly happen in the morning.

In the context of gender, crimes often happen to men in the morning and in the afternoon. For women, it mostly happens in the morning. Logically, it could be concluded that the security at Trans Semarang bus stop is far from having the human scale in the morning. The respondent responses towards the connectivity is based on some reasons. Women who have limited mobility, do a lot of activities in the morning (go to the market, school, work, drop by children to school, go shopping or selling in the market) (Delbose and Currie, 2011 in (Verma et al., 2017). The activities density at that time, it might cause less awareness of the women to the security around the bus stop. At the end, it might cause women to become the victims or witnesses of the crimes. For men, the crimes are easier to happen because most of the perpetrators are men, so it is easier for eyeing the victims in the bus stop or in the BRT armada

Table 2. The influence of gender towards the connectivity of using time BRT and the crime experiencing

\begin{tabular}{|c|c|c|c|c|c|}
\hline \multirow{3}{*}{$\begin{array}{l}\text { Gender } \\
\text { Time Using BRT }\end{array}$} & \multirow{2}{*}{\multicolumn{4}{|c|}{$\begin{array}{l}\text { Men } \\
\text { Crime Experience }\end{array}$}} & \multirow{3}{*}{ TOTAL } \\
\hline & & & & & \\
\hline & Yes & No & Yes & No & \\
\hline Morning (6.00 a.m.-9.00a.m.) & $7 \%$ & $3 \%$ & $8 \%$ & $13 \%$ & $31 \%$ \\
\hline Daylight (11.00 a.m.-1.00 p.m.) & 0 & $6 \%$ & $2 \%$ & $13 \%$ & $21 \%$ \\
\hline Afternoon (4.00 p.m.-6.00 p.m.) & 0 & $2 \%$ & 0 & $10 \%$ & $12 \%$ \\
\hline Morning and Afternoon & $10 \%$ & $6 \%$ & $7 \%$ & $6 \%$ & $29 \%$ \\
\hline Others & $1 \%$ & $1 \%$ & $1 \%$ & $4 \%$ & $7 \%$ \\
\hline TOTAL & $18 \%$ & $18 \%$ & $18 \%$ & $46 \%$ & $100 \%$ \\
\hline
\end{tabular}

Source: Researcher Analysis, 2019 
From the above result, it could be concluded that the crimes in BRT bus stop do not relate with the gender grouping on the age and certain sexes (percentage 18\%). All BRT passengers have the potential to become the crime target, especially when the BRT bus stop is full (mostly at Balaikota transit bus stop). At this bus stop, the BRT officers more concern with the departure and arrival (transit or non-transit), comparing with the security of the bus stop. Undoubtfully if the crimes happen in BRT bus stop miss from the officer's supervision. The type of crimes are also different towards men or women, men usually experience crimes in the form of pickpocket or stealing, but women mostly experience sexual harassment.

Besides that, the minimum knowledge of passengers about the crimes and security of BRT bus stop also becomes the reason. For example, women (mostly at the school age) often get violence (physical or verbal) from older passengers (mostly men), but it is considered common for other passengers. It seems that BRT passengers apply gender inequality (the victims do not need help, or they should take care of themselves). Even the victims are often blamed because of the way they dress, their behaviour or other passengers ignore the fear of the victims in mobility.

In the context of human scale, activities and the surrounding support the criminal case. The surrounding of BRT bus stop in Pandama area is rather quiet in the morning (except Hotel Santika, Balaikota, and Theresiana bus stops) due to the minimum activities (the area is dominated by housing, unoperational public space or disfunctional private space). Many cases happened because there is no activity in the connection passage Trans Semarang bus stop (pedestrian way, zebra cross or bridge). The activities which only use built-up area make the passengers the crime target in BRT bus stop. The outside route of Pandanaran, the distance between the bus stop and the distance to the connection transportation mode is hard to reach (outside the radius $400 \mathrm{~m}$ ), and it might cause the activity connection disparity and bus stop space.

Besides that, the connection between the human scale and crime can be evaluated from the waiting time of BRT (independent variable). From the following table, it can be concluded that men and women have the crime experience at almost the same waiting time range. The same probability crime is at the range of 9-10 minutes. Women who wait longer for BRT (more than 15 minutes) are more vulnerable to become crime victims than men. But men passengers who wait more than 20 minutes (percentage 4\%) are also possible to become the victims, even the probability is bigger than women.

Table 3. The Influence of Gender Towards The Connection of Time Waiting at BRT Bus Stop and Crime Experience

\begin{tabular}{lccccc}
\hline \multicolumn{1}{c}{ Gender } & \multicolumn{2}{c}{ Men } & \multicolumn{3}{c}{ Women } \\
\multicolumn{1}{c}{ Waiting Time BRT } & & \multicolumn{3}{c}{ Crime Experience } & TOTAL \\
& Yes & No & Yes & No & \\
\hline 0-5 Minutes & $4 \%$ & $2 \%$ & $4 \%$ & $4 \%$ & $14 \%$ \\
5-10 Minutes & $2 \%$ & $9 \%$ & $2 \%$ & $18 \%$ & $31 \%$ \\
10-15 Minutes & $3 \%$ & $4 \%$ & $2 \%$ & $13 \%$ & $22 \%$ \\
15-20 Minutes & $5 \%$ & $3 \%$ & $7 \%$ & $5 \%$ & $20 \%$ \\
More Than 20 Minutes & $4 \%$ & 0 & $3 \%$ & $6 \%$ & $13 \%$ \\
TOTAL & $18 \%$ & $18 \%$ & $18 \%$ & $46 \%$ & $100 \%$ \\
\hline
\end{tabular}

Source: Researcher Analysis, 2019

In the context of human scale theory, the longer time of waiting should enable the passengers to control the surrounding space or object. But the disability to control the bus stop space and its surrounding could happen because of some reasons. First, during the waiting time for armada arrival, the passengers do not pay attention to the surrounding and focus on their own activities (see the cell phone or talking with friends). Second, when the passengers are waiting for Trans Semarang, the surrounding Pandama area is quiet enough or activities in a certain area create space exclusivism (offices, banks). Third, the situation at 
the BRT bus stop create inconvenience (noisy, dark, hot, etc) and it makes the passengers do not have a close connection with the bus stop space. At the end, some of those factors create vulnerable passengers and without self-protection towards the crime case at BRT bus stop.

Then, if we see the crime probability in the BRT time waiting range less than 10 minutes, it might be influenced by some external factor. For example, the housing in Pandama area (city kampong) is prone to crime, so the BRT passengers have become the crime target since the start location. Second, a special case in Balaikota transit bus stop, the passengers could become the crime target since they were inside BRT (dynamic movement, Newton, 2004). Because of the limited space, the perpetrators might do their crimes in the transit bus stop/bus stop when the passengers get in and off the armada.

\section{Impact on gender travel patterns}

Crime experience of BRT passengers at one point has an impact on the individual mobility pattern in gender identity. This research is trying to divide the possibility behavioural changing into four types: changing the time departure (temporary or permanent), changing the starting point of the bus stop, changing the trip pattern, or changing the transportation mode. Most of the passengers who experienced crimes directly or indirectly will change the transportation mode or are not willing to use the BRT again. Moreover, it is supported with the choice of private transportation mode like private vehicles (low credit installments), online vehicles (Go-Jek, Grab), or other public transportation like angkot, taxi or city bus.

Through the passenger's responses, the majority (percentage $41 \%$ ) do not choose to change their behaviour or to change with another mentioned categories (dressed closed, careful, learn self-defense martial). This is based on the judgment that BRT is safe relatively, effective and has a certain route with time accuracy. Even the passengers in the part of the percentage decided not to change anything whether they experience crime in the future or not. The other respondents decided to change the behaviour pattern for safety and convenience in doing activities with various reasons.

Table 4. The Influence of Gender Towards The Connection of Behavioural Changing and Crime Experience

\begin{tabular}{|c|c|c|c|c|c|}
\hline \multirow{3}{*}{$\begin{array}{l}\text { Gender } \\
\text { Behavioural Changing }\end{array}$} & \multicolumn{2}{|c|}{ Men } & & men & \multirow{3}{*}{ TOTAL } \\
\hline & \multicolumn{4}{|c|}{ Crime Experience } & \\
\hline & $\overline{\text { Yes }}$ & No & Yes & No & \\
\hline Time Using BRT & $5 \%$ & $1 \%$ & $2 \%$ & $5 \%$ & $13 \%$ \\
\hline Bus Stop Origin Point & $2 \%$ & $4 \%$ & $6 \%$ & $5 \%$ & $17 \%$ \\
\hline Travel Pattern & $3 \%$ & $1 \%$ & $3 \%$ & $3 \%$ & $10 \%$ \\
\hline Transportation Mode & $6 \%$ & $2 \%$ & $4 \%$ & $7 \%$ & $19 \%$ \\
\hline Others/None & $2 \%$ & $10 \%$ & $3 \%$ & $26 \%$ & $41 \%$ \\
\hline TOTAL & $18 \%$ & $18 \%$ & $18 \%$ & $46 \%$ & $100 \%$ \\
\hline
\end{tabular}

Source: Researcher Analysis, 2019

In the context of gender, every respondent in any group (sexes, age, activity, trip route) who have crime experience, tend to change the mobility pattern positively. Men with the ability and choices in various mobility (ride a motorcycle or car), choose to change transportation mode (riding their own vehicles). Women who have limited mobility (more expensive cost, limited ability) prefer to change the starting point of BRT bus stop. Moreover, women ride their own vehicles are often underestimated in traffic. Thus, the vulnerability of women is often become the target victims of cars/motorcycles stealing or are vulnerable to sexual harrassment in other choices of transportation mode. In the end, that makes BRT still becomes the best choice. Thus, the availability of the BRT officers helps to supervise the security at BRT bus stop and also the seat separation between men and women. 
Here are some reasons related to the changing behaviour of the passengers, such as afraid to experience the same crime/trauma, and considering the safety and self-protection On the other hand, the respondents who do not change their behaviour, have their own reasons such as:

- $\quad$ Respondents do not trust in the news easily (it could be a hoax)

- $\quad$ BRT schedule is suited with the respondent activity

- There is only one public transportation mode to reach the goal location

- The changes take more time and longer route

- Another route is considered causing more congestion which obstructed the activity.

\section{CONCLUSIONS}

This research is trying to find whether the human scale (Trans Semarang bus stop) has a correlation with Pandama crime rate based on gender identity. Data is conducted by questionnaire in 100 respondents at Pandama bus stops. The correlation is based on 3 basic indicators, which are the time using BRT, the waiting time at the bus stop, and the changes in human behaviour (independent variable). The cross-tabulation analysis is used to analyze statistical data, with crime and gender as a dependent variable. The result is human scale might reduce the Trans Semarang bus stop crime rate in gender. There are some reasons supporting the result. First, men and women who traveling with Trans Semarang in the morning (6.00-9.00 a.m.) might experience a criminal case than traveling at another time. Second, there are no gender differences in crime case during the waiting time. The longer the waiting time is, the probability of criminal case is higher. Third, most men and women passengers choose not to change anything when doing activity in BRT bus stop. Even though in the future they will experience crime cases (Trans Semarang claimed to be still effective and safe). Fourth, the main factor is how Trans Semarang passengers are able to create close connectivity with Trans Semarang bus stop space and its surrounding. Space capacity expansion at Trans Semarang bus stop, the emergency button facility, the activities arising at the connection path and its surrounding might be able to minimize the crime cases and crime perceptions.

In the context of gender, there are various intervention that could improve gender mobility in the context to achieve the idealism of human scale and to decrease the number of urban crimes. It is important to create a safe and comfortable Trans Semarang bus stop especially for women. For example by providing women security/police women inside the bus stop, the expansion of bus stop capacity with the allocation for women passengers, women priority hotline crime information and the addition of Trans Semarang armada in peak hours of women mobility. From outside, it should be good lightning in the early morning and at night at each bus stop, provide colorful design (red, yellow, orange) and safety connection path to Trans Semarang bus stop to enhance women mobility in every possible hour and activity. The safety regulations for women about crime in Trans Semarang bus stop should be implied in deeper research. Since women have less mobility than men, future research might also review general gender mainstreaming regulations regarding the indicators of human scale. It is expected to strengthen the individual safety rights in Trans Semarang bus stop directly. 


\section{REFERENCES}

Ari D.P. 2015. Polisi Kejar Pelaku Pelecehan Seksual di BRT Semarang. Article retrieved from www.jateng.tribunnews.com.

Azali, I. 2018. Preferensi Konsumen Terhadap Transportasi Publik (Studi Kasus Bus Rapid Transit/BRT Kota Semarang). Jurnal Media Ekonomi Dan Manajemen.33(1):86-98.

Calcatinge, A. 2012. The need for a cultural landscape theory: An architect's approach (Vienna): LIT Verlag.

Caminha, C. et al. 2017. Human Mobility in Large Cities as A Proxy or Crime. PloS ONE:12(2).

Campbell, C. J. 2018. Space, place and scale: Human Geography and Spatial History in Past and Present. Past and Present.239(1):e24-e45.

Ceccato, V. 2013. Moving safely: Crime and Perceived Safety in Stockholm's Subway Station (Lexington: Lanham.

Ceccato, V. et al. 2017. Women's Mobility and the Situational Conditions of Rape: cases Reported to Hospitals. Journal of Interpersonal Violencel. 1-30.

Ceccato, V. 2017. Women's Victimisation and Safety in Transit Environments. Crime Prevention Community Sad.19:163-167.

Cervero, et al. 2009. Influences of Built Environment on Walking and Cycling: Lessons from Bogota. Sustainable Transportation. 3(4):203-226.

Cohen, L. E. \&Felson, M. 1979. Social Change and Crime Rate Trends: A Routine Activity Approach. American Sociological Review.44(4):588-608.

Corbusier, L. 1960. Precisions -Sur un Etat Present de I'Architecture et de I'Urbanisme (Paris): Editions Vincent Freal.

Daniels, R. \&Mulley, C. 2011. Explaining walking distance to public transport: the dominance of public transport supply. Journal of Transport and Land Use.6(2):5-27.

Gekoski, et al. 2016. The Prevelance, Nature, and Impact of Intrafamilial Child Sexual Abuse: Findings from a Rapid Evidence Assessment. Journal of Criminological Research, Policy, and Practice.2(4):231-243.

Harris, C. L, Jackson, A. P. \&Valentine, G. 2017. Attitudes Towards the 'Stranger': Negotiating Encounters with Difference in the UK and Poland. Social and Cultural Geography.18(1):16-33.

Jacobs, J. 1961. The Death and Life of Great American Cities. (New York): Vintage Books.

Gehl, J. 2010. Cities for People. (London): Island press.

Lawson, B. R. 2010. Healing Architecture. Arts and Health.2(2):95-108.

Lacono, M., Krizek, K., \&El-Geneidy, A. 2010. Measuring non-motorized accessibility: issues, alternatives and executionMeasuring non-motorized accessibility: issues, alternatives and execution. Journal of Transport Geography.18:133-140.

Lawson, B. 2001. The language of space. (Oxford): Architectural Press.

Loukaitou-Sideris, A. Liggett, R. \&Iseki, H. 2002. The Geography of Transit Crime Documentation and Evaluation of Crime Incidence on and around the Green Line Stations in Los Angeles. Journal of Planning Education and Research.22(2):135-151.

Loukaitou-Sideris, A. 2014. Fear and safety in transit environments from the women's perspective. Security Journal.27(2):242-256.

Loukaitou-Sideris, A. 2016. A Gendered View of Mobility and Transport: Next Steps and Future Directions. The Town Planning Review.87(5):547-565.

McDowell, L. 1993. Space, Place, and Gender Relations: Part I. Feminist Empiricism and the Geography of Social Relations. Programme Humanity Geography.17(2):157-179.

Morgan, R. \&Smith, M. J. 2016. Crimes Against Passengers: Theft, Robbery, Assault, and Indecent Assault. Secure and Tranquil Travel: Preventing Crime and Disorder on Public Transport (London: jill Dando Institute of Crime Science).77-102.

Mumford, L. 1961. The City in History (San Diego): Harcourt Inc.

Newman, O. 1972. Defensible space: Crime prevention through urban design. (New York): MacMillan.

Newton, A. D. 2004. Crime on Public Transport: 'Static' and 'Non-Static' (Moving) Crime Events. Western Criminology.5(3):25-42.

Papagiannakis, A., Baraklianos I., \&Spyridonidou, A. 2016. Urban Travel Behaviour and Household Income in Times of Economic Crisis: Challenges and Perspective for Sustainable Mobility. Transport Policy.65:51-60.

Parwito. 2018. Petugas Trans Semarang Tangkap Tangan Copet Residivis Saat Beraksi di BRT. Article retrieved from www.radarsemarang.com.

Permadi, G. 2017. Copet Beraksi di Shelter BRT, Akhirnya Jadi Begini. Article retrieved from www.radarsemarang.com.

Plyusthteva, A. \&Schwanen, T. 2018. Geoforum Care-Related Journeys Over the Life Course: Thinking Mobility Biographies with Gender, Care, and the Household. Geoforum.97:131-141.

Schumacher, E. F. 1973. Small is Beautiful (London): Blond and Briggs.

Shach-Pinsly, D. 2018. Measuring Security in the Built Environment: Evaluating Urban Vulnerability in a Human-Scale Urban Form. Landscape and Urban Planning.ISSN 0169-2046.

Speer, J. 2015. Henri LeFebvre: Spatial Politics, Everyday Life and the Right to the City. The AAG Review of Books.3(1):4-5. 
Spicer, V. 2012. The geometry of Fear: An Environmental Perspective on Fear and the Perception of Crime (US): Simon Fraser University.

Spicer, V \&Song, J. 2017. The impact of transit growth on the perception of crime. Journal of Environmental Psychology:54:151-159.

Stark, J. \&Meschik, M. 2018. Women's Everyday Mobility: Frigthening Situations and Their Impacts on Travel Behaviour. Transportation Research Part F: Traffic Psychology and Behaviour.54:311-323.

Tulumello, S. 2017. Toward a Critical Understanding of Urban Security within the Institutional Practice of Urban Planning: The Case of the Lisbon Metropolitan Area. Journal of Planning Education and Research.37(4):397-411.

Verma et al. 2016. Service Gap Analysis of Public Buses in Bangalore With Respect to Women Safety. Transportation Research Procedia.25:4322-4329. 